NBER WORKING PAPER SERIES

\title{
SHORT-RUN INDEPENDENCE OF MONETARY POLICY UNDER PEGGED EXCHANGE RATES AND EFFECTS OF MONEY ON EXCHANGE RATES AND INTEREST RATES
}

\author{
Alan C. Stockman \\ Lee E. Ohanian
}

Working Paper No. 4517

\author{
NATIONAL BUREAU OF ECONOMIC RESEARCH \\ 1050 Massachusetts Avenue \\ Cambridge, MA 02138 \\ November, 1993
}

This paper is part of NBER's research program in International Finance and Macroeconomics. Any opinions expressed are those of the authors and not those of the National Bureau of Economic Research. 


\title{
SHORT-RUN INDEPENDENCE OF MONETARY POLICY UNDER PEGGED EXCHANGE RATES AND EFFECTS OF MONEY ON EXCHANGE RATES AND INTEREST RATES
}

\begin{abstract}
Economists generally assert that countries sacrifice monetary independence when they peg their exchange rates. At the same time, central bankers frequently assert that pegging an exchange rate does not eliminate the independence of monetary policy. This paper examines the effects of money-supply changes on exchange rates, interest rates, and production in an optimizing two-country model in which some sectors of the economy have predetermined nominal prices in the short run and other sectors have flexible prices. Money-supply shocks have liquidity effects both within and across countries and induce a cross-country real-interest differential. The model predicts that liquidity effects are highly non-linear and are not likely to be captured well empirically by linear models, particularly those involving only a single country. The most striking implication of the model is that countries have a degree of short-run independence of monetary policy even under pegged exchange rates.
\end{abstract}

\author{
Alan C. Stockman \\ Department of Economics \\ University of Rochester \\ Rochester, NY 14627 \\ and NBER
}

\author{
Lee E. Ohanian \\ Department of Economics \\ University of Pennsylvania \\ Philadelphia, PA 19104
}




\section{Introduction}

This paper examines the effects of money-supply changes in two-country world in which some sectors of the economy have nominal prices that are sticky in the short run and other sectors have flexible prices. We examine the short-run effects of changes in the money supply on the exchange rate, home and foreign real and nominal interest rates, and production in each sector and in each country. We show that money-supply changes have liquidity effects (a fall in the money supply raises the real and nominal interest rate) both within and across countries, and introduce a cross-country real-interest differential. We also show how a country can exercise independent monetary policy, in the short run, while it pegs its exchange rate to another country. Similarly, the model shows why a credible target zone for the exchange-rate provides much less of a short-run constraint on monetary policy than is commonly believed.

Our closed-economy paper examined the questions of how a change in the money supply affects nominal prices in the flexible-price sectors. It discussed the conditions under which those nominal prices overshoot their long-run equilibrium levels in the short run, and when they undershoot those levels. It also showed that a only a small sector of the economy need be subject to sluggish nominal-price adjustment for a money-supply change to generate a liquidity effect of the size found in most estimates. It provided an alternative model of liquidity effects to the model developed in Feurst [8], Lucas [12], and Christiano and Eichenbaum [4] (following earlier related work by Grossman and Weiss [10]and Rotemberg [18]).

Economists currently lack an empirically satisfactory model of exchange rates. Many 
theoretical models assign a large role to monetary disturbances, operating through mechanisms closely related to that expounded in the classic contribution of Dornbusch [6]. Other theoretical models (e.g. [23] and [13]) assign a larger role to real disturbances that affect equilibrium relative prices and induce exchange-rate changes to create them. Recent empirical evidence suggests that exchange rates may contain a mean-reverting component with a half-life of approximately three years (e.g. [11], [5], and [14]). Yet current theoretical models that connect changes in money, interest rates and international interest-differentials, and exchange rates have not successfully explained these short-term changes in exchange rates. Similarly, equilibrium models of exchange rates have not been successful in explaining the observed differences in relative-price behavior across alternative exchange-rate systems (see [22], [15], and [1]). Moreover, none of the current theoretical models can explain the apparent short-run independence of monetary policy that countries can exercise under pegged exchange rates, or under systems of limited exchange-rate flexibility such as the EMS.

This paper develops an alternative theoretical framework in which monetary disturbances may play an important role in affecting interest rates and exchange rates. Unlike most previous research on the real effects of monetary shocks that has focused on a onesector macroeconomic model (such as [6] and [16]), we examine a two-sector model and allow the two sectors to have different degrees of price flexibility. (We examine the simple case in which one sector's price is completely sticky in the short run and the other sector's price s completely flexible.)

Our interest in this two-sector model follows from the empirical finding that nominal price flexibility varies considerably across different goods. For example, there appear to be certajn goods with prices that change very infrequently, as documented by Blinder, Carlton, 
Cechetti, Kashyap,and Kindahl and Stigler. Alternatively, there are goods with prices that change often, such as relatively homogeneous goods sold on near-auction markets, food, gasoline, antomobiles (transaction prices), and computers. The two-sector model presented in this paper generates substantially different predictions than one-sector models about the connections between changes in money, interest rates, international interest-rate differentials, and exchange rates. In addition, the model predicts that credible limits on exchange-rate changes create less stringent constraints on short-run monetary policy than is implied by previous models. The model suggests a re-assessment of the questions of whether exchange-rate changes are caused mainly by monetary or real disturbances and how exchange rates are connected with changes in interest rates or international interestrate differentials, the balance of trade, output, and employment. The model can be used for positive analysis as well as welfare analysis of alternative exchange rate systems and of alternative monetary policies within each system. The model suggests new channels through which monetary policy is transmitted internationally and the differences in international transmission under different exchange-rate systems.

There has been much discussion of sterilization of international reserve flows under pegged exchange rates or systems of limited exchange-rate flexibility. But there has been little analysis of the process through which sterilization occurs or its implications for other economic variables. Similarly, despite a large literature on the economics of target zones for exchange rates, there has been little analysis of the short-run effects of monetary policy under a target-zone system. These issues are connected because the same forces that give countries the ability to conduct independent monetary policies in the short run under pegged exchange rates allow's them to do so nnder a system of target zones, even when the exchange 
rate is at the edge of that zone. Stockman [19] finds empirical evidence that countries were able to conduct independent monetary policies under the Bretton-Woods System of pegged exchange rates - policies that had liquidity effects on home nominal and real interest rates, that created international real-interest differentials, and that had temporary effects on the home rate of inflation (and so resulted in short-run differences in inflation across countries under pegged exchange rates). Svensson [25] similarly finds evidence of short-term monetary independence within the EMS.

While neither existing sticky price nor equilibrium exchange rate models are consistent with this evidence, the current paper presents a model in which a country can use monetary policy to create short-run changes in its real and nominal interest rates (creating an international real-interest differential) and short-run changes in its inflation rate at the same time it pegs its exchange rate. We show that countries, at times, have an entire set of monetary policies from which to choose, and that each choice has different implications for other real and nominal economic variables. The set consists of an interval of money-supply changes: as long as the money-supply change is within the interval, the exchange rate remains pegged As in [17], we treat price stickiness in these sectors as a black box because there is no well-established theory to explain the evidence that many nominal prices adjust slowly. In this paper we concentrate on the effects of negative monetary shocks. ${ }^{1}$ Positive monetary shocks would have the opposite effects, assuming that output is determined by the quantity demanded (as it would be if we begin from a situation of excess supply, as in a model with monopolistic competition such as [3]).

\footnotetext{
'We do this to avoid taking a otand on whether ontpot is determined by the quantity supplied or the quantity demanded when thete is excess demad. Our closed-economy paper discuses this issue further.
} 
This paper does not attempt to match the implications of the model with actual data. Nor do we deal with dynamics or with uncertainty and risk, or with the issues of industrial organization and imperfect competition that have played major roles in recent closedeconomy models of the effects of money and the effects of price-sluggishness. Instead, we keep the model as simple as possible to examine the new channels of economic interaction that can occur in a two-country, two-sector model.

\section{The Model.}

\subsection{A Closed Economy}

We outline here the closed-economy model from [17]. Consider a closed economy with two goods, $X$ and $Y$, money introduced through cash-in-advance constraints, and complete asset markets. A representative household maximizes discounted expected utility:

$$
\max \sum_{t=0}^{\infty} \beta^{t}\left[\frac{1}{(1-\rho)}\left(\alpha x_{t}^{(\sigma-1) / \sigma}+(1-\alpha) y_{t}^{(\sigma-1) / \sigma}\right)^{(\sigma /(\sigma-1)) \cdot(1-\rho)}-v\left(L_{X t}+L_{Y t}\right)\right]
$$

subject to the sequence of constraints

$$
P_{X, t-1} k_{X, t-1} L_{X, t-1}^{\delta}+P_{Y, t-1} k_{Y, t-1} L_{Y, t-1}^{\delta}+\nu_{t}\left(g_{t}+d_{t}\right)+T_{t}-\nu_{t+1} q_{t}-M_{t}=0
$$

and

$$
M_{t}-P_{X t} X_{t}-R_{Y_{t}} Y_{t}=0
$$

where (2) is a budget constraint for period-t asset markets and (3) is the cash-in-advance constraint which applies to period-t product markets (which immediately follow period-t asset markets as in [13]). 
The terms $x$ and $y$ refer to consumption of goods $X$ and $Y, L_{X}$ and $L_{Y}$ refer to labor hours producing goods $X$ and $Y, P_{X}$ and $P_{Y}$ are nominal prices, $k_{X}$ and $k_{Y}$ are exogenous productivity parameters, $0 \leq \delta \leq 1$ is a parameter of the production function, $\nu_{t}$ is a vector of assets the household owns at the beginning of period $t$ with dividend vector $d_{t}$ and ex-dividend price-vector $q_{t}, \tau_{t}$ is a lump-sum transfer of money to the household from the government at the beginning of period $t$, and $M_{t}$ is the nominal money the household has as it leaves period-t asset markets and enters period-t product markets. We assume that momentary utility is of the CES form, with $\sigma=$ the elasticity of substitution between the two goods, $x$ and $y$, and $\rho=$ the coefficient of relative risk aversion. For the special case $\sigma=\rho=1$, we obtain $\log$ utility: $U=\alpha \log (x)+(1-\alpha) \log (y)$.

Assume that the cash-in-advance constraint (3) binds as an equality, that $k_{X} \equiv k_{Y} \equiv 1$, and that $\tau \equiv 0$ for all $t$. It is easy to see that the fexible-price perfect foresight equilibrium for this simple production economy satisfies

$$
\begin{aligned}
& M_{t}^{*}=P_{X t} L_{X t}^{\delta}+P_{Y t} L_{Y t}^{\delta}, \\
& P_{X t} \lambda_{t}=\left(\alpha I_{t}^{(\sigma-1) / \sigma}+(1-\alpha) y_{t}^{(\sigma-1) / \sigma}\right)^{(1-\infty) /(\sigma-1)} \alpha k_{X} L_{X t}^{-\delta / \sigma}, \\
& P_{Y_{t}} \lambda_{t}=\left(\alpha x_{t}^{(\sigma-1) / \sigma}+(1-\alpha) y_{t}^{(\sigma-1) / \sigma}\right)^{(1-\infty) /(\sigma-1)}(1-\alpha) k_{Y_{t}} L_{Y t}^{-\delta / \sigma}, \\
& v=\beta P_{X t} \delta k_{X t} L_{X t}^{\delta-1} \lambda_{t+1}
\end{aligned}
$$

and 


$$
v=\beta R_{Y_{t}} \delta k_{Y_{t}} L_{Y_{t}}^{\delta-1} \lambda_{t+1}
$$

where $M_{i}^{\prime}$ is the (exogenous and constant, because $T=0$ ) money supply at the end of period- $t$ asset markets and $\lambda$ is the current-value Lagrange multiplier on constraint (3). (Note that $\lambda=\gamma$, the multiplier on (2), because of the first-order condition for the choice of $M_{t}$.) Moreover, we can solve for the nominal interest rate on a one-period nominal asset using the pricing formula:

$$
i=\frac{\lambda_{t}}{\beta \lambda_{t+1}}-1
$$

\subsubsection{Closed-Economy Equilibrium when Some Prices are Sticky}

Suppose there are high costs of changing the nominal price $P_{X}$ except at the end of each period, so sellers choose $P_{X}$ at the end of period $t-1$. The nominal price $R_{Y}$, however, is perfectly flexible. Begin with a nonstochastic steady-state equilibrium with a constant money supply, and consider a small unanticipated, permanent change in $M_{t}$ at the beginning of period $t$. Real variables dated at $t+1$ and later are unaffected by this change in the money supply, but real variables at date $t$ change because $P_{X, t}$ is predetermined.

A permanent fall in money creates excess-supply for good $X$ in the short run because $P_{X, \ell}$ is above its new equilibrium level, and as a result, output of $X$ is demand-determined. So equation (7) (describing the supply of $X$ ) does not hold in the short run. Instead, we have equations (4)-(6) and (8) in the four variables $L_{X, t}, L_{Y, t}, R_{Y, t}$, and $\lambda_{t}$, (with $\lambda_{t+1}$ taking its new steady state value). Because a change in the money supply has no steadystate effect on $x, y$, or $L_{X}$, equation (5) implies it also leaves $P_{X, \ell+1} \lambda_{t+1}$ unchanged. Since the percentage fall in money lowers $P_{X, t+1}$ by the same percentage, it also must raise $\lambda_{t+1}$ 
by that percentage.

In [17] we also discuss the excess-demand case after the money supply rises, starting from an equilibrium. In the excess-demand case, output of the sticky-price good $X$ is supply-determined. In this paper we will concentrate on excess-supply situations, following a fall in the money supply from equilibrium. The results can be re-interpreted to give the effects of an increase in the money supply, starting from a position of excess supply. We show in our other paper that the sign of the cross-derivative in utility takes the sign of $(1-\rho \sigma)$,that a fall in the money supply causes a smaller percentage fall in $P_{Y}$ if the elasticity of substitution in consumption, $\sigma$, exceeds one, and a larger fall in $A_{y}$ if $\sigma<1$, and that a fall in the money supply raises the one-period interest rate if and only if the degree of relative risk aversion, $\rho$, exceeds one. Numerical results in that paper showed that fairly large liquidity effects occur even if only a small fraction of GDP has sticky nominal prices. A fall in money raises nominal and real interest rates, reduces aggregate GDP, and has different effects on output in the sticky-and flexible-price sectors.

\subsection{A Two-Nation World Economy}

Now consider a two-country version of the model. Each country is identical to the closed economy described above. Each produces and consumes two internationally-tradable goods, $X$ and $Y$, using only labor as an input. Now there are two moneys introduced through cashin-advance constraints with the usual convention in which the money used is that of the seller's country (see e.g. [13]). Because the two countries are identical ex ante, we describe only the domestic country. As before, a representative household in the home country 
maximizes

$$
E_{0} \sum_{t=0}^{\infty} \beta^{t}\left[\frac{1}{(1-\rho)}\left(\alpha x_{t}^{(\sigma-1) / \sigma}+(1-\alpha) y_{t}^{(\sigma-1) / \sigma}\right)^{(\sigma /(\sigma-1)) \cdot(1-\rho)}-v\left(L_{X_{t}}+L_{Y_{t}}\right)\right]
$$

Now, however, the household is subject to the sequence of budget constraints

$$
P_{X, t-1} k_{X, t-1} L_{X, t-1}^{\delta}+R_{Y, t-1} k_{Y, t-1} L_{Y, t-1}^{\delta}+\nu_{t}\left(q_{t}+d_{t}\right)+\tau_{t}-\nu_{t+1} q_{t}-M_{t}-e_{t} N_{t}=0
$$

and sequences of the two cash-in-advance constraints,

$$
M_{t}-\min \left\{\bar{x}_{t}, x_{t}\right\} P_{X_{t}}-\min \left\{\bar{y}_{t}, y_{t}\right\} P_{\gamma_{t}}=0,
$$

and

$$
N_{t}-\max \left\{x_{t}-\bar{x}_{t}, 0\right\} P_{X_{t}}-\max \left\{y_{t}-\bar{y}_{t}, 0\right\} P_{Y_{t}}^{*}=0,
$$

where (11) is a budget constraint for period-t asset markets and (12) and (13) are the cash-in-advance constraints that apply to period-t product markets.

The terms $x_{t}$ and $y_{t}$ now refer to total home consumption of goods $X$ and $Y$, regardless of where the goods were purchased, $\bar{x}_{t}$ and $\bar{y}_{t}$ refer to home production of the two goods, $M_{i}$ is the home household's stock of home money at the beginning of the product market, and $N_{t}$ is its stock of foreign money, used for purchasing imports (if imports are positive).

We now abandon the complete-markets assumption. We assume assets cannot be traded conditional on monetary transfers or taxes (positive or negative $\tau$ ). So any decrease in the home money supply is financed by lump-sum taxes (negative $\tau$ ) on households in the home country only, and analogously any decrease in the foreign money supply directly affects foreign households only. 
Assume as before that $\tau \equiv \tau^{*} \equiv 0$, where $\tau^{*}$ is the transfer or tax in the foreign country, and $k_{X, t}=k_{X *, t}=k_{Y, t}=k_{y-t}=1$ for all $t$. It is easy to see that one flexible-price equilibrium is the same as in the closed economy, with no international trade or foreignmoney holding (by the home country). (The other equilibria involve higher levels of wealth in one country than in the other.) In the equal wealth equilibrium that we will focus on, relative prices and allocations are identical in each country.

\subsection{World Equilibrium When Some Prices Are Sticky}

Now consider the world equilibrium when $P_{X}$ and $P_{X}^{*}$ (the foreign-currency nominal price of $X$ produced and sold in that country) are chosen one period in advance. The nominal prices $B_{Y}$ and $P_{\dot{Y}}$, are completely flexible. We initially consider a situation of flexible exchange rates, and hold constant the foreign money supply $N^{S}$ as we vary the home money supply $M^{S}$ unexpectedly. As in the closed-economy model, we begin at a nonstochastic steady-state equilibrium with constant money supplies, and consider a small unanticipated, permanent fall in $M_{t}^{S}$.

Since we no longer have a representative household (the absence of markets to share the risk of taxes and transfers to change the money supply can lead such transfers or taxes to redistribute wealth internationally), we need to specify a rationing rule stating which buyers (foreign or domestic) are able to buy what number of goods when there is excess demand in a market, and from which sellers they buy if there is excess supply. (In each case, we treat all buyers from a single country as identical - they all buy the same amount, and we treat all sellers from a single country as identical - they all sell the same amount. In that sense we ignore results in the literature which show that in situations like this, a 
distribution of prices and sales can arise ex post even if sellers are identical ex ante.) We assume that if there is excess supply, buyers always purchase goods from the sellers in the country with the lowest price (after adjusting for the current exchange rate), and that if the price is the same in both countries, they buy first from sellers in their own country. (They also may buy some of the product from sellers in the other country; we will see later that this is what can make the price the same across countries.) We assume that in situations of excess demand for a good in country $A$, buyers who live in country $A$ are first in line, and buyers from the other country are last in line to buy the good. Places in line may not be traded. There is also no cost of waiting in line (no transactions costs of rationing).

Despite the simplicity of our model economy, there are a number of possible cases that can arise in this two-country world. We now consider these cases in turn.

\subsubsection{Case 1: Excess Supply in the Home Country and Excess Demand in the Foreign Country}

First consider situations in which there is excess supply of $X$ in the home country and excess demand for $X$ in the foreign country. Since we begin from a nonstochastic steadystate equilibrium (in which the law of one price holds for each good), this situation arises if the domestic money appreciates, rajsing the relative price of $X$-in-the-home-country in terms of $X$-in-the-foreign country. Denoting by $e$ the exchange rate (in units of home money per unit of foreign money), we have $P_{X}>e P_{\dot{X}}^{*}$. There are three possible sub-cases within this situation (and in which good $X$ continues to be produced in the home country). First, foreigners may buy all the good $X$ offered for sale in their country, and may be unwilling to buy any good $X$ from the home country at the higher price there). Residents of the home 
country, being unable to import good $X$ by definition of the rationing rule, must purchase the good from sellers in their own country. There is no trade in good $X$ in this case. All the necessary conditions(5), (6), (7), (8), and their foreign counterparts hold, except the corners in this situation imply

$$
P_{X}^{*} \lambda_{i}^{*}<\left(\alpha x_{t}^{*(\sigma-1) / \sigma}+(1-\alpha) y_{t}^{*(\sigma-1) / \sigma}\right)^{(1-\infty) /(\sigma-1)} \alpha L_{X i}^{*-\delta / \sigma}
$$

n:hich says that foreign marginal utility of consumption of $X$ exceeds the foreign price times the marginal utility of foreign wealth (meaning that foreigner buyers are rationed in buying $X)$

$$
\left(P_{X t} / e_{t}\right) \lambda_{i}^{*}>\left(\alpha x_{t}^{*(\sigma-1) / \sigma}+(1-\alpha) y_{t}^{*(\sigma-1) / \sigma}\right)^{(!-\infty) /(\sigma-1)} \alpha L_{X i}^{*-\delta / \sigma},
$$

which says that foreign buyers choose not to buy any $X$ from the home country, because the price there is too high (after adjusting for the exchange rate), and

$$
v<\beta P_{X t} \delta k_{X t} L_{X t}^{\delta-1} E \lambda_{t+1}
$$

which says that there is excess supply of $X$ at home, so home sellers are rationed (they cannot sell all they would like to produce at the existing price).

In the second possible sub-case, foreigners may buy all the good $X$ offered for sale in their country, and may also be willing to buy some good $X$ from the home country, even at the higher price there. Residents of the home country, being last in line in the foreign country and so unable to import good $X$, buy it from sellers in their own country. Again $P_{X}>e P_{X}^{\bullet}$ and all the necessary conditions(5), (6), (7), (8), and their foreign counterparts hold except that the corners now imply (14), (??) and

$$
\left(P_{X i} / e_{t}\right) \lambda_{i}^{*}=\left(\alpha x_{i}^{-(\sigma-1) / \sigma}+(1-\alpha) y_{t}^{*(\sigma-1) / \sigma}\right)^{(1-\infty) /(\sigma-1)} \alpha L_{X i}^{--\delta / \sigma}
$$


which says that foreign buyers choose an internal optimum (rather than a corner solution) for buying $X$ from the home conntry. Notice that in contrast to the first sub-case, there is international trade: the home country exports good $X$.

In the third sub-case, foreigners may be anconstrained in buying good $X$ in their own country. Then home residents, who are last in line there, are able to purchase some good $X$ from the foreign country, where it is cheaper because $P_{X}>e P_{X}^{*}$, and buy the rest from sellers in their own country. Again all the necessary conditions(5), (6), (7), (8), and their foreign counterparts hold, in addition to (17) and

$$
\epsilon_{t} P_{X 1}^{*} \lambda_{1}<\left(\alpha x_{t}^{(\sigma-1) / \sigma}+(1-\alpha) y_{i}^{(\sigma-1) / \sigma}\right)^{(1-\infty) /(\sigma-1)} \alpha k_{X 1} L_{X i}^{-\delta / \sigma}
$$

which says that home residents are constrained from buying more good $X$ at the lower foreign price. Notice that in this case the home country imports good $X$.

In each of these three sub-cases, we also have (9) and an analogous equation for a foreigncurrency one-period nominal interest rate. We also have the law of one price for good $Y$, $R_{Y}=e P_{Y}^{*}$, and interest-parity (covered and uncovered interest parity are the same in this nonstochastic model):

$$
e_{t}=e_{t+1} \frac{\lambda_{i}^{*}}{\lambda_{t+1}^{*}} \frac{\lambda_{t+1}}{\lambda_{t}},
$$

where $\lambda^{*}$ is the multiplier on the foreign representative household's current-period budget constraint. Equation (19) follor's directly from the usual expression of interest parity $\left(e^{\prime} / e=\right.$ $(1+i) /(1+i *))$ and $(9)$ and its foreign counterpart. In addition; we need the separate budget constraints for home and foreign households. The home household can buy (or sell) one-period nominal bonds $B$ at the price $1 /(1+i)$.

In this ex-ante equal wealth world, we assume that initially there is no international 
indebtedness. But after the change in the money supply in one of the countries (or both), $B$ can become non-zero, in which case it turns out to remain non-zero in the new steady state. If $B$ is positive in the new steady state, (which corresponds to the second sub-case with the home country exporting $x$ in the short run), the home country consumes the interest $i B /(1+i)$ each period in that new steady state. So during the period $(t)$ in which the money supply first changes, the budget constraint for the home household states that total spending on the two goods (which will occur at two different prices if $P_{X} \neq e P_{\bar{X}}$ ), plus spending on bonds equals total nominal labor income (from the prior period's production and sales of goods) minus the decrease (or plus the increase) in the home money supply, $M_{i}^{S}$ at date $t$. For example, in the third sub-case discussed above, the home household spends

$$
P_{Y_{t}} y_{t}+P_{X, t} \overline{x_{t}}+e P_{X, t}^{*}\left(x_{t}-\overline{x_{t}}\right)
$$

on goods because it buys some $X$ from home sellers and the rest from the (lower-price) foreign sellers. This spending, plus spending on bonds $B_{t} /\left(1+i_{t}\right)$, must be financed by labor income $P_{X, t-1} k_{X, t-1} L_{X, t-1}^{\delta}+P_{Y, t-1} k_{Y, t-1} L_{Y, t-1}^{\delta}$ minus the fall (or plus the increase) in the home money supply. The household's budget constraint for subsequent periods $t+j$, $j \geq 1$ (in the new steady state) allows it to spend on goods $i_{t+j} B_{t} /\left(1+i_{t+j}\right)$ more than its labor income each period. (The household can also buy or sell more bonds in the future, but does not do so in equilibrium.)

\subsubsection{Case 2: Excess Demand in the Home Country and Excess Demand in the Foreign Country}

We have discussed situations in which there is excess supply for $X$ in the home country and excess demand in the foreign country. We now turn to the other possible situations. There 
may be excess demand for $X$ in the home country and excess supply in the foreign country; this situation is symmetric to the situation already discussed, and 80 can arise in the three sub-cases that are described above. Another possible case involves excess demand for $\boldsymbol{X}$ in both countries. This can also arise in three possible sub-cases.

In the first sub-case, the home household may be at a corner solution in buying $X$ at home, so that

$$
P_{X i} \lambda_{t}<\left(\alpha x_{i}^{(\sigma-1) / \sigma}+(1-\alpha) y_{i}^{(\sigma-1) / \sigma}\right)^{(1-\infty) /(\sigma-1)} \alpha L_{X i}^{-\delta / \sigma}
$$

and an analogous condition may hold for the foreign household in buying $X$ in the foreign country. In that case, there is no international trade (because domestic residents in each country are first in the rationing lines). In the second sub-case, the home household may be at an interior solution for buying $X$ from home sellers, but the foreign household may be at a corner in buying from foreign sellers,

$$
P_{X i}^{*} \lambda_{i}^{*}<\left(\alpha x_{i}^{*(\sigma-1) / \sigma}+(1-\alpha) y_{t}^{*(\sigma-1) / \sigma}\right)^{(1-\infty) /(\sigma-1)} \alpha L_{X i}^{*-\delta / \sigma},
$$

and also at a corner in buying from home sellers (see equation 17). In this case, the home country exports good $X$. The third possible sub-case is symmetric to the second sub-case: the foreign household is at an interior optimum for buying $X$ from foreign sellers, but there is excess demand for $X$ in both countries because the home household is at a corner solution in buying from both home and foreign sellers. 


\section{Foreign Country}

The final disequilibrium situation that is possible consists of excess supply for good $X$ in both countries. This requires $P_{X}=e P_{X}^{-}$, otherwise buyers would raise the quantity demanded in the lower-price market. This situation can occur if, for example, the money supply falls unexpectedly by the same percentage in each country; the equilibrium would then be identical to the closed-economy case, with no international trade. But this situation can also arise in a much more interesting case: if the money supply falls by a larger percentage in the home country than in the foreign country, one might expect the domestic money to appreciate and for both countries to have excess supply of good $X$, which is subject to the short-run nominal-price sluggishness. But that would make $\boldsymbol{X}$ cheaper in the foreign country than in the home country, and would lead buyers to substitute out of home purchases of $X$ toward foreign purchases. At the same time, buyers can substitute out of foreign purchases of $Y$ toward home purchases of $Y$. This occurs until the extra demand for $X$ in the foreign country raises its price relative to home $X$. Since the foreign-money price of $X$ in the foreign country is sticky in the short run, as is the home-money price of $X$ at home, this relative price change alters the exchange rate. (The mechanism is analogous to the effects of real shocks on the real and nominal exchange rate in equilibrium models of exchange rates, such as [23] and [13]- see Stockman [21].) The striking aspect of this disequilibrium situation is that (because $P_{X}$ and $P_{X}^{*}$ do not change in the short run), it results in a fixed exchange rate in the short run. We will use this fact to show how countries can have short-run independence of monetary policy - affecting real and nominal variables 
- even under pegged exchange rates.

\section{Short-Run Effects of a Fall in Home Money}

We now turn to the implications of the two-country model, which we obtain from numerical calculations (using a non-linear equation solver). This is necessary because we generally cannot obtain analytic solutions to the model with the CES atility function. Our previous paper on the closed-economy case ([17]) showed that a one-time unexpected fall in the money supply raises real and nominal interest rates in the short run (if the coefficient of relative risk aversion exceeds one), reduces output of goods in the sticky-price sector, and reduces $P_{Y}$ in percentage terms by more or less than the money-supply fall depending on whether the elasticity of substitution in consumption is less than or greater than one.

Consider a permanent, unexpected $2 \%$ fall in the home country's money supply (from 10 to 9.8 ), starting from a steady-state equilibrium with a constant money supply and price level. We hold fuxed the foreign money supply in this initial exercise. Table 1 shows the results when (in each country) $\alpha=.5, \sigma=0.5, \delta=.9, v=1, \beta=.99, \rho=2$, and each money supply is initially 10. This means half of GDP in each country consists of output of good $Y$, the relative price of $Y$ in terms of $X$ is initially unity, the exchange rate is initially one, and the real (and nominal) interest rate is $i / \beta-1$. Since $\sigma<1$, the two goods are relatively poor substitutes. We also assume there is no initial international indebtedness, so initially the countries are identical and there is no international trade. The first column of Table 1 shows the endogenous variables: the nominal price of $Y$ in the home and foreign countries (py and pyf), the nominal interest rate (in percent) in the home and foreign 
countries ( $i$ and $i f)$, the exchange rate $(e)$, the real exchange rate $\left(e p^{-} / p\right)$ labor inputs in the $x$ industry in the home and foreign countries ( $l x$ and $l x f$ ), labor inputs in the $y$ industries in the home and foreign countries (ly andly $f$ ), GNP in the home and foreign countries evaluated at the equilibrium prices and production shares (GNP and GNPf) and total labor supply in the home and foreign countries ( $n$ and $n f$ ). The second column, "Old SS," shows the old steady-state levels of the variables (before the change in money) from which the analysis begins. The "SR" column shows the short-run effects of the fall in money (while the nominal price of $X$ is fixed at its previous level for one period). The "New SS" column shows the new steady state, and the column labeled "percent" shows the percentage by which a variable falls short of or exceeds its new steady state level. For the interest rate, this column presents the difference between interest rates in the short-run and in the new steady state.

The $2 \%$ fall in money leads, in the long run ("New SS" column) to a $2 \%$ fall in the nominal prices of goods $X$ and $Y$, from 7.333 to 7.187 . (The new steady state relative price of $Y$ in terms of $X$ is one, so the new price of $X$ is also 7.187.) The interest rate is unaffected in the long run by the one-time change in the level of money, and the exchange rate falls $2 \%$ from 1.00 to 0.98 in the long run. Long-run levels of employment in each industry in the home country (lx and ly) are unaffected, as are foreign employment levels in each industry (lx $f$ and $l y f)$ and long-run levels of output in each industry and in each country (prod $-x, \operatorname{prod}-y, \operatorname{prod}-x f$, and $\operatorname{prod}-y f$ ). The negative level of bonds indicates that the home country borrows in the short run and becomes a net debtor in the new steady state, though the level of the interest on this debt is sufficiently small that (to a four-decimal-point approximation) consumption in each country is the same as its domestic production in the 
long run.

While the unexpected change in money is almost neutral in the long run ("almost" because it redistributes wealth and 60 has permanent effects), it is not neutral in the shortrun. The impact effect of the unexpected fall in home money is to raise the home-country nominal interest rate by 53 basis points. If one interprets this as a quarterly model (since the discount parameter is .99 per period), with one-quarter nominal price stickiness in the $X$ industry, then the steady state interest rate is $1.01 \%$ per quarter, or $4.04 \%$ per year. Then the $2 \%$ fall in home money raises the annualized home nominal interest rate by 211 basis points, to $6.15 \%$ per year. The foreign nominal interest rate also rises, by 47 basis points on a per-period basis, which is 188 basis points on an annualized basis with this interpretation. The home nominal interest rate is then 20 basis points above the foreign rate on an annualized basis. This is reflected also in a slight overshooting of the exchange rate in the short run (it falls five one-hundredths of a percent below .98) followed by a 6mall expected (and actual) appreciation of home currency. Output and employment in the home country fall in both industries, but production falls significantly in the $X$ industry with sticky prices. Overall output is unchanged in the foreign country, though there is a small sectoral reallocation of production from the $X$ industry to the $Y$ industry. As noted previously, the home country borrows in the short run from the foreign country, and it imports both goods on net, running a balance of trade deficit to smooth consumption, which falls less than output in each industry. Table 1 also shows a slight rise in momentary utility, or felicity, in the home country: this occurs because households in the home country get more current utility from the increased leisure they have than from the fall in consumption (because international borrowing allows them to decrease current consumption by less than 
outpot falls), though there is a slight fall in present-value utility (which appears unchanged at the accuracy shown in the table) as the home country exports goods in the new steady state and its future consumption is slightly smaller than it would otherwise have been.

Notice that, in the short run, the appreciation of home currency combined with the stickiness of both the home-money price of $X$ sold at home and the foreign-money price of $X$ sold abroad implies that $X$ is cheaper in the foreign country than in the home country. There is, in the short run, excess demand for $X$ in the foreign country and excess supply in the home country. Foreigners are unconstrained in buying good $X$ in their own country and home residents, who are last in line there, import $X$ and buy the rest from sellers in their own country. (This is the third sub-case discussed in section 2.3 .1 that can result in excess supply in the home country and excess demand in the foreign country, with the corner solution represented by equation (18).)

The intuition behind the results in Table 1 is easier to understand by first considering the case in which both countries reduce their money supplies by the same percentage. The result is the same in each country as in a closed economy, and there is no international trade in either the short run or in the new steady state. Table 2 shows the effects of an unexpected, permanent $2 \%$ fall in money in both countries. This has identical effects in the two countries, so we can discuss only the home country. The fall in money reduces aggregate nominal spending, which reduces the nominal price of good $Y$. Because $P_{X}$ is fixed in the short run, this increases the relative price of $X$, so consumers substitute good $Y$ for $\operatorname{good} X$, which further reduces output of $X$ and works against the fall in spending on $Y$. If the elasticity of substitution in consumption, $\sigma$, were one, output in the $Y$ sector would remain unchanged, and the nominal price of $Y$ would fall by $2 \%$. With $\sigma<1$ (as 
Tables 1 and 2 assume), output of $Y$ falls along with output of $X$ and $P Y$ overshoots its long-run fall. (If $\sigma>1$, output of $Y$ rises and its nominal price undershoots its longrun fall.) Table 2 shows that the marginal ntility of income measured in nominal terms ("lambda") rises by about $3 \%$ in the short run, though its long-run increase is naturally only $2 \%$. This occurs because households would like to smooth consumption over time to borrow from the (higher) steady-state level of consumption to offet partly the fall in current consumption. The marginal atility of one "dollar" is higher currently than it will be in the future. The attempts to borrow raise the nominal interest rate in the short run. (Notice the closed-economy liquidity effect is about twice the size of the liquidity effect in Table 1.) Of course, since the nominal price of $X$ is expected to fall next period (to its new long-run equilibrium level), and the nominal price of $\boldsymbol{Y}$ is not expected to change much, there is overall expected deflation, which means the overall real interest rate rises even more than the nominal rate. Our closed-economy paper discusses these issues in further detail.

Now return to the results in Table 1, where only the home money supply falls. If these were two closed economies, the results for the home country would be identical to those in Table 2, and no changes would occur in the foreign country. One can imagine a "shadow exchange rate" for that case: since the law of one price for good $Y$ applies, the fall in $R_{Y}$ and the constancy of $P_{Y}^{*}$ imply that the home currency would appreciate. This would make good $X$ cheaper in the foreign country than in the home country and lead consumers in the home country to try to import good $X$ (further increasing the excess supply for $X$ in the home country). Home consumers are last in line for foreign output when it is in excess demand, but this creates excess demand for $X$ in the foreign country. Consumers in the home country want to borrow to buy both $X$ and $Y$, so the real interest rate measured in 
terms of each good rises. Since the expected change in the nominal price of either good in the foreign country is negligible, this rise in the real rate occurs through a rise in the nominal rate of interest in the foreign country. The law of one price for good $Y$ and the facts that $P_{Y}^{*}$ does not change much, and $F_{Y}$ falls roughly $2 \%$ (see Table 2) guarantee that the exchange rate falls about $2 \%$. This means that the expected change in the exchange rate is very small (there is not much overshooting), so interest-parity implies that the home nominal interest rate rises about as much as the foreign rate. Home consumers face a higher relative price for good $X$ than do foreign consumers, so home consumption of $X$ drops by more than foreign consumption of $X$, while the home and foreign countries both reduce consumption of $Y$ by about the same amount (home consumption falls slightly more because of complementarity of $X$ and $Y$ in home utility).

Table 3 shows the effects of a $2 \%$ fall in the home money supply when $\sigma=2$. The other parameters are the same as in Table 1, and again the fall in money is unexpected and permanent. The results are similar to those in Table 1, but a few important differences emerge when the elasticity of substitution between $x$ and $y$ exceeds one. First, the nominal price of $Y$ undershoots its new long-run equilibrium level. This occurs because the larger is $\sigma$, the greater the extent to which consumers try to substitute out of consumption of $X$ and into consumption of the relatively cheaper good $Y$. This leads to a higher demand for $Y$ and raises its price (as compared to Table 1). Given that the price of $I$ is fixed, and that the price of $y$ undershoots, it appears that the overall price level is "sticky" in this economy. The exchange rate also undershoot its new long-run equilibrium level. (To see why, consider what would happen to the shadow exchange rate if the two economies were closed: it would fall by the same proportion as $P_{Y}$.) The undershooting of the exchange 
rate, combined with interest parity, implies that the foreign nominal interest rate rises more than the home nominal interest rate. The other main difference when $\sigma>1$ is that home output in the $Y$ sector rises somewhat; this is caused by the greater degree of substitution by consumers away from $X$ when $P_{Y}$ falls. Table 4 shows the effects of changing the utility parameter $\alpha$ : it sets $\alpha=.6$ rather than .5 as before. This raises the fraction of overall employment in the sticky-price sector from $1 / 2$ as before to about $2 / 3$. A $2 \%$ fall in home money has quantitatively larger real effects than when the share of the sticky-price sector was smaller; the table provides an idea of the size of those effects. Similarly, Table 5 shows the effects of the fall in money when $a=.4$, which implies the share of total labor working in the sticky-price sector is about $1 / 3$.

\section{Pegged Exchange Rates and Short-Run Monetary Inde- pendence}

We have already discussed the effects of permanent changes in the money supply in one country. We now consider the effects of changes in the money supplies of both countries, and we focus on monetary policies in the foreign country that peg the exchange rate, or that lead to sufficiently small changes in the exchange rate that for all practical purposes it is pegged. One way for the foreign country to peg its exchange rate (in the absence of any other shocks) is to change js money supply in proportion to the change in the home money supply; call this the baseline path of foreign money. We will see that temporary changes in the foreign money supply around this baseline path can also result in a pegged exchange rate, but cause changes (relative to the baseline path) in output, real and nominal interest 
rates, relative prices, and international trade.

Suppose the home country's money supply falls by $2 \%$ as in Tables 1 and 2 , and suppose the foreign country pegs its exchange rate (at unity). Suppose also that the foreign government can credibly commit to a future path for the money supply. Because nominal prices are set one period in advance, for only one period, anticipated future changes in money can be fully incorporated into price-setting behavior.

One way for the foreign government to peg the exchange rate is to follow the baseline path for money, with results as in Table 2. But Tables 6a-6d show that there are also other ways to peg the exchange rate. Table $6 a$ shows the results of a foreign monetary policy that reduces the foreign money supply $3 \%$, from $M^{S_{*}}=10$ to $M^{S_{*}}=9.7$ in the short run (while the home money supply falls from 10 to 9.8 ), and then changes $M^{S *}$ to 9.80098 in the long run, assuming that $\alpha=.5, \sigma=0.5, \delta=.9, v=1, \beta=.99, \rho=2$, as in Table 1. The exchange rate remains at exactly one, the rise in world interest rates of 203 basis points exceeds the 100-basis-point rise that occurs along the baseline path, there is a greater fall in output of the $Y$-sector in both countries (a $0.93 \%$ fall rather than a $0.47 \%$ fall), a larger fall in output in the $X$-sector in the foreign country $(2.98 \%$ rather than $1.49 \%)$, a smaller fall in output in the $X$-sector in the home country $(0.97 \%$ rather than $1.49 \%)$, a slightly smaller fall in labor in the home country (1.06\% rather than $1.09 \%)$, and a much greater fall in labor in the foreign country (2.18\% rather than $1.09 \%)$. In contrast to the baseline case, the foreign country imports good $X$, importing about $1 \%$ of its consumption of $X$, and financing these imports mainly by borrowing (and only to a very small extent by exporting good $Y$ ). The foreign trade deficit in the short run creates a (small) long-run trade surplus, as the country pays interest on its debt each period in the long run. 
If the $3 \%$ fall in the foreign money supply were permanent, the foreign currency would appreciate. However, the temporary nature of the fall, followed by a return to something close to the baseline path, implies that the exchange rate will remain fixed. To see why, consider what would happen were the foreign currency to appreciate. Because nominal prices in the $X$ industry are predetermined, good $X$ would be cheaper in the home country than in the foreign country. Foreign consumers would try to import good $X$ rather than buying it in their own country. Originally, there was excess supply of $X$ in each country; now there is smaller excess supply of $X$ in the home country and greater excess supply in the foreign country. The increased demand for $X$ cannot raise $P_{X}$, which is predetermined. But it raises the value of home currency on the foreign exchange market - until the relative price of good $X$ across countries is again unity. (If the fall in the foreign money supply is large enough, excess demand is created in the home country and the relative price never reaches unity; this happens, for example, if the foreign money supply falls to 9.6 in this example.) Foreign consumers import just enough $X$ to assure that the price is unity: if they imported less, it would be cheaper to buy $X$ in the home country and imports would rise; if they imported more, it would be cheaper to buy $X$ in the foreign country, and imports would fall.

The exchange rate adjusts to assure the "right" relative price of goods just as in equilibrium models of exchange rates (see Stockman, 1980, 1988). In this case, the exchange rate adjusts to get the "right" relative price of $X$ across countries, and international trade in that good adjusts accordingly. Because the foreign country runs a current-account deficit in the short run, there is a permanent effect on the distribution of wealth across countries, and given that long run monetary policy is chosen to keep the exchange rate unchanged, 
the money supply does not return exactly to the baseline path in the new steady state.

Table $6 b$ shows the results when the foreign money supply falls less than the baseline case: it falls from 10 to 9.85 for one period and then permanently goes to 9.79952 (while home money falls to 9.8). We continue to consider the case in which $\alpha=.5, \sigma=0.5, \delta=.9$, $v=1, \beta=.99$, and $\rho=2$. If the fall to 9.85 were permanent, foreign currency would depreciate and $X$ would be cheaper in the foreign country. This would add to excess supply for $X$ in the home country and reduce excess supply of $X$ in the foreign country; this occurs up to the point at which the relative price is unity, i.e. at an unchanged exchange rate. In this case the rise in world interest rates is smaller ( 49 basis points) than in the baseline case, the foreign country exports $X$, home output of $X$ falls more and foreign output of $X$ falls less than in the baseline case, while output of $Y$ falls less in both countries.

Table $6 c$ shows the results when the foreign money supply falls even less in the short run - from 10 to 9.9 , before permanently going to 9.79904 . In this case the exchange rate continues to be pegged, but there is no liquidity effect on the world nominal interest rate. The foreign country runs a trade surplus by exporting $X$ as in Table $6 b$, and it is larger than in that table, but now the only good whose output is affected (much) is $X$ in the home country. The fall in foreign money has virtually no effect on foreign output in the short run.

Table $6 d$ shows the results when the foreign money supply falls even less - from 10 to 9.95, before permanently going to 9.79857 . In this case the exchange rate remains constant, and nominal interest rates in each country fall rather than rise, despite the fall in money supplies in each country. As in Tables 6a-6c, there is excess supply for $X$ in both countries. As in Tables $6 b-6 c$, the foreign country has a trade surplus mainly connected with exports 
of $X$. In contrast to these other tables, while output of $X$ in the home country falls, output of $X$ in the foreign country rises, and output of $Y$ rises slightly in both countries.

These tables illustrate three important points. First, there is an entire range of money supplies from which the foreign country can choose in the short run even as it maintains a pegged exchange rate. In contrast to existing theoretical models of exchange rate determination, pegging the exchange rate does not prevent the government from exercising monetary independence in the short run.

Second, each choice from this range has different consequences for real and nominal variables. Production, consumption, the pattern of international trade and borrowing on international financial markets, and real and nominal interest rates differ depending on the choice. Moreover, the direction of changes in many of these variables, not just the magnitude of the changes, depends on the choice of the money supply in the short run.

Third, one should not expect the relation between changes in the money supply and (say) nominal interest rates to depend solely on domestic monetary policy. The short-run responses of variables such as nominal interest rates depend heavily on foreign as well as home money-supply shocks. And the sign of the effect (as well as its size) depends partly on how similar or dissimilar are the money-supply changes across countries. The high degree of non-linearity in the response of nominal interest rates to changes in the money supply, illustrated by these tables, suggests that linear vector-autoregressions are likely to miss key features of the relations between money and interest rates.

The results in the previous tables do not imply that the ability of a country to peg its currency in the short run depends on its choosing the "right" level of the money supply in the long run. That long-run choice of money is essential only for permanent pegging of 
the exchange rate. Table 7 illustrates this point. It shows the effects of a permanent $1 \%$ fall in the foreign money supply when the home money supply falls by $2 \%$. The failure of the foreign country to adjust its new steady-state money supply appropriately prevents the exchange rate from remaining pegged in the long run. But the exchange rate nevertheless remains pegged in the short run. Notice also that although the foreign money supply falls permanently by less than the home money supply, in the short-run its interest rate rises more.

The ability of the foreign country to choose its money supply independently while pegging the exchange rate does, however, depend on the behavior of the home money supply. In the absence of excess supply for $X$ in the home country, the foreign country's independence vanishes. Table 8 illustrates this fact. Here, the home money supply remains fixed at 10 while the foreign money supply falls permanently to 9.9 . This creates foreign-currency appreciation in the short run as well as the long run. Similarly, Table 9 shows the effects of a temporary fall in foreign money to 9.9 while it chooses long-run money to peg the long-term exchange rate at unity. Despite the long-run pegging, the short-run fall in the money supply is not consistent with a short-run exchange-rate peg because there is not excess supply in the home country.

Our experiments with altering relative country size indicate that the main difference in the results when one country is much larger than the other concern the size of the liquidity effect of a change in money in the small country. While the small country maintains a high degree of short-run monetary independence under pegged exchange rates, it can have only a small effect on its own (and the world) nominal interest rate. 


\section{Extensions}

The goods produced in each country are perfect substitutes in the model discussed above. We generalized the model to study the robustness of our results with respect to this assumption. First, we replaced the assumption that good $X$ produced in the home country is a perfect substitute for good $X$ produced in the foreign country. We now treat $X$ as a composite of two goods, $r$ and $q$, produced in the home and foreign countries, where

$$
x_{i}=\left(\lambda q_{t}^{(\psi-1) / \psi}+(1-\lambda) r_{i}^{(\psi-1) / \psi}\right)^{(\psi /(\psi-1))}
$$

is a CES aggregator of goods $q$ and $r$, the sticky-price goods produced in the home and foreign countries. By varying the elasticity of substitution between these goods, $\psi$, we can study the consequences of less-than-perfect substitutability between home and foregin goods.

The results, in Tables $10 a-10 c$, are striking. We assume the share paramenter $\lambda$ equals one-half and the elasticity of substitution $\psi$ equals 2 . Table 10a shows the results when the money supply falls 2 percent in each country, as in Table 2. Tables 10b and 10c show the results when the foreign country reduces money permantly by 2 percent, as does the home country in the long run, but when the home country holds money fixed in the short run or reduces money by 4 percent in the short run. The exchange rate is no longer ezactly fixed at unity, but when the home country keeps its money suply fixed in the short run the exchange rate rises (home currency depreciates) less than three-tenths of one percent in the short run. Similarly, when the home country reduces its money supply by four percent in the short run (and two percent in the long run), its currency appreciates by less than 
three-tenths of one percent. Although the exchange rate is not exactly fixed, it changes very little in the short run. Since countries with pegged exchange rates always permit the exchange rate to change over a small band, this result indicates that the assumption of perfect substitutability between foreign and domestic goods is not required to obtain a degree of short-run monetary independence nnder pegged exchange rates.

Second, we generalized this model by adding another good, $z$, which has a small expenditure share, is produced in both countries, has a sticky price in the short ran (as $q$ and $r$ do), and for which $z$ produced in either country is a perfect substitute. This good is intended to capture the fairly standardized goods produced around the world for which there is evidence of sticky nominal prices. We modified the utility function and added the utility of this good, $\Omega z^{(1-\xi)} /(1-\xi)$, to the utility function above. We then equated $\xi$ and $\rho$ and varied $\Omega$ to vary the expenditure share on good $z$. The results are even more striking. Regardless of how small is the share of expenditure on good $z$, we reproduce the qualitative results of the previous section: there is a range of money supplies for one of the countries (holding fixed the money supply in the other coutnry) that results in an exactly pegged exchange rate. The smaller $\Omega$, the smaller the expenditure share of good $z$, and the smaller the band of money supplies (the smaller the range of short-term monetary independence). Suppose the foregin country reduces its money supply permanently by 2 percent, from 10 to 9.8. If the expenditure share on $z$ is one percent, the home money supply can fall anywhere between 9.74 and 9.86 in the short run while maintaining an exactly-pegged exchange rate. If the expenditure share on $z$ is two percent, the range is 9.7 to 9.9 ; if the epxenditure share on $z$ is ten percent, the range widens to 9.35 to 10.22 . (The home country can even reise its money supply in the short run and maintain an exactly-pegged exchange rate.) In our 
experiments, the size of the band in percentage points is about ten times the size of the expenditure share on good z. These generalizations of our model indicate that our results regarding short-term independence of monetary policy are robust to several assumptions of the model.

\section{Conclusions}

One of the oldest debates in international monetary economics concerns the ability of countries to sterilize international reserve flows under regimes of pegged exchange rates or systems of limited exchange rate variability, such as the EMS. While central bankers typically assert that they have this flexibility, and empirical evidence is supportive of this claim, existing theoretical models of exchange rate determination, including sticky price models (e.g. Dornbusch), and equilibrium models (e.g. Stockman, Lucas), are silent on this issue. This paper developed an optimizing two-country, two good model in which the degree of price flexibility varies across different sectors of the economy, and uses the model to investigate the effects of money supply changes on the exchange rate, home and foreign nominal and real interest rates, sectoral production in each country, and the pattern of international trade. We demonstrated how monetary shocks can have liquidity effects on interest rates both within and across countries, and can introduce a cross-country interest differential. Unexpected changes in money affect sectoral production as well as overall GDP. An important new result of our two-sector model is that a country can peg its exchange rate while maintaining a high degree of short-term independence of monetary policy. 


\section{References}

[1] Marianne Baxter and Alan Stockman (1989), "Business Cycles and the Exchange-Rate Regime: Some International Evidence," Journal of Monetary Economics 23, no. 3, May $1989,377-400$.

[2] Ben Bernanke and Alan Blinder (1992), "The Federal Funds Rate and the Channel6 of Monetary Transmission," American Economic Review

[3] Olivier Blanchard and Nobu Kiyotaki (1987), "Monopolistic Competition and the Effects of Aggregate Demand," American Economic Review 77 no. 4, 647-666

[4] Larry Christiano and Martin Eichenbaum (1992), "Liquidity Effects, Monetary Policy, and the Business Cycle," Northwestern University working paper

[5] Robert E. Cumby and John Huizinga, "The Predictability of Real Exchange Rate Changes in the Short Run and Long Run," NBER working paper 3468, 1990.

[6] Rudiger Dornbusch, "Expectations and Exchange Rate Dynamics," Journal of Political Economy 84 (1976), 1161-76.

[7] Charles Engel (1991), "Is Real Exchange Rate Variability Caused by Relative Price Changes? An Empirical Investigation," University of Washington working paper

[8] Tim Feurst (1992), "Liquidity, Loanable Funds, and Real Activity," Journal of Monetary Economics

[9] Stanley Fischer (1977), "Long-Term Contracts, Rational Expectations, and the Optimal Money-Supply Rule," Journal of Political Economy 
[10] Sanford Grossman and Laurence Weiss (1983), "A Transactions-Based Model of the Monetary Transmission Mechanism," American Economic Review

[11] John Huizinga (1987), "An Empirical Investigation of the Long-Run Behavior of Real Exchange Rates," Carnegie-Rochester Conference Series 27, 149-214.

[12] Robert E. Lucas, Jr. (1990), "Liquidity and Interest Rates," Journal of Economic Theory

[13] Robert E. Lucas, Jr. (1982), "Interest Rates and Currency Prices in a Two-Country World, Journal of Monetary Economics

[14] Nelson Mark (1992), "Exchange Rates and Fundamentals: Evidence on Long-Horizon Predictability and Overshooting," Ohio State University working paper

[15] Michael Mussa (1986), "Nominal Exchange Rate Regimes and the Behavior of Real Exchange Rates," Carnegie-Rochester Conference Series on Public Policy 25, 1986, $117-214$

[16] Michael Mussa (1982), "A Model of Exchange-Rate Dynamics," Journal of Political Economy 90 (1982), 74-104.

[17] Lee Ohanian and Alan C. Stockman (1993), "Real Effects of Money when Some Prices Are Stickyn unpublished, University of Rochester

[18] Julio Rotemberg (1984), "A Monetary Equilibrium Model with Transactions Costs," Journal of Political Economy 92, 40-48 
[19] Alan C. Stockman (1992), "International Transmission under Bretton Woods," in Michael Bordo and Barry Eichengreen (eds.), A Retrospective on Bretton Woods, University of Chicago Press.

[20] Alan Stockman (1988), "Real Exchange Rate Variability under Pegged and Floating Nominal Exchange Rate Systems: An Equilibrium Theory," in K. Brunner and A.H. Meltzer (eds.), Carnegie-Rochester Conference Series on Public Policy 29, Spring, 1988, 259-94.

[21] Alan C. Stockman, "The Equilibrium Approach to Exchange Rates," Economic Review, Federal Reserve Bank of Richmond, March-April, 1987, 12-31.

[22] Alan Stockman (1983), "Real Exchange Rates under Alternative Nominal Exchange Rate Systems," Journal of International Money and Finance 2 (August, 1983), 147-66.

[23] Alan C. Stockman, "A Theory of Exchange Rate Determination," Journal of Political Economy 88 (1980), 673-98.

[24] Lars E.O. Svensson (1986), "Sticky Goods Prices, Flexible Asset Prices, Monopolistic Competition, and Monetary Policy," Review of Economic Studies 3 no. 174, 385-405.

[25] Lars E.O. Svensson (1992), "Why Exchange Rate Bands? Monetary independence in Spite of Fixed Exchinge Rates" IIER, October 1992.

[26] Lars E.O.Svensson and Sweder van Wijnbergen (1989), "Excess Capacity, Monopolistic competition, and International Transmission of Monetary Disturbances, The Economic Journal 99 September, 785-805. 